\title{
Novel protective group synthesis of androgen receptor modulators with steroidal and nonsteroidal scaffolds
}

\author{
Matthias Grill ${ }^{1}$, Melanie Patt ${ }^{2}$, Alex Odermatt ${ }^{2 *}$
}

${ }^{1}$ Lipomed AG, Fabrikmattenweg 4, 4144 Arlesheim, Switzerland.

${ }^{2}$ Division of Molecular and Systems Toxicology, Department of Pharmaceutical Sciences, University of Basel, Klingelbergstrasse 50, 4056 Basel, Switzerland.

*Address of correspondence: Dr. Alex Odermatt, Swiss Centre for Applied Human Toxicology and Division of Molecular and Systems Toxicology, Department of Pharmaceutical Sciences, University of Basel, Klingelbergstrasse 50, 4056 Basel, Switzerland.

Alex.Odermatt@unibas.ch, phone: + 41612071530.

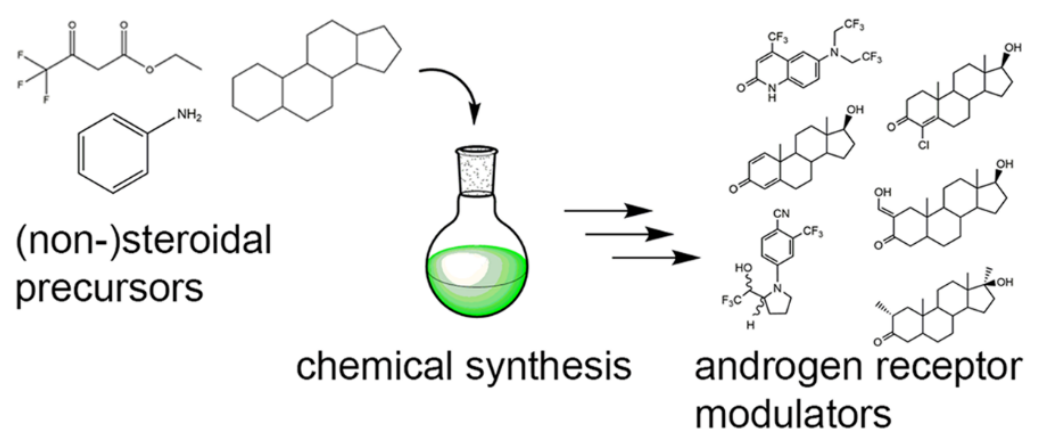

\begin{abstract}
Anabolic androgenic steroids (AAS) are frequently used either clinically, by athletes, or for body shaping due to their muscle building and performance enhancing properties. AAS misuse is associated with cardiovascular diseases, mood changes and endocrine issues. Despite the recognition of the severe adverse effects of AAS misuse, the underlying molecular mechanisms are insufficiently understood. Selective androgen receptor modulators (SARMs) are supposed to diminish the adverse androgenic AAS effects while maximizing anabolic effects. In order to obtain androgen receptor modulating compounds of high purity for mechanistic in vitro investigations, this study summarizes protocols of optimized chemical synthesis for five AAS and two SARMs.
\end{abstract}


The procedures described exhibit the following advantages:

1. straightforward, easily reproducible synthesis method

2. high purity achieved

3. low cost chemical synthesis

\section{Keywords}

steroid synthesis; anabolic androgenic steroids; selective androgen receptor modulators

\section{Method details}

\section{Synthesis of drostanolone:}<smiles>CC12CCC(=O)CC1CCC1C2CCC2(C)C1CC[C@@H]2OC1CCCCO1</smiles>

STEP I: Androstan-17ß-((tetrahydro-2H-pyran-2-yl)oxy)-3-one (1)

Facilitating higher yields, the application of the tetrahydropyranyl-(THP)-group in order to protect the $17 \beta$-alcohol as a THP-ether was established:

$3.53 \mathrm{~g}$ Dihydropyran was added dropwise to a solution of $10.2 \mathrm{~g}$ dihydrotestosterone in $200 \mathrm{ml}$ dichloromethane under argon at room temperature, followed by the addition of a solution of 0.100 g pyridinium tosylate in $13 \mathrm{ml}$ dichloromethane.

After $20 \mathrm{~h}$ stirring at room temperature, TLC showed 80\% conversion. An additional amount of $0.420 \mathrm{~g}$ dihydropyran and $0.010 \mathrm{~g}$ pyridinium tosylate were added to the solution and stirring continued for another $24 \mathrm{~h}$. After this period, a total conversion of approx. $90 \%$ could be monitored by TLC. 
The reaction mixture was diluted with $200 \mathrm{ml}$ dichloromethane and then washed with water and saturated sodium chloride solution. The combined organic extracts were dried over $\mathrm{MgSO}_{4}$ and evaporated to yield $16.50 \mathrm{~g}$ of colorless foam.

The crude product was chromatographed on silica gel by using hexane-ethyl acetate (1:1) as an eluent. The isolated product was obtained as a colorless solid (13.10 g; 99\%).

MS (ESI $)^{+}$:

$m / z=374.89$ (calculated MW: $374.56 \mathrm{~g} / \mathrm{mol}$ )

$\mathrm{R}_{\mathrm{f}}$ : 0.7 , hexane/ethyl acetate $1: 1$, visualized by Seebach derivatization reagent.<smiles>CC12CC(=CO)C(=O)CC1CCC1C2CCC2(C)C1CC[C@@H]2OC1CCCCO1</smiles>

STEP II: 2-Hydroxymethylene-androstan-17ß-((tetrahydro-2H-pyran-2-yl)oxy)-3-one (2)

13.00 g Intermediate (1) was completely dissolved in $200 \mathrm{ml}$ dry tetrahydrofuran. $1.09 \mathrm{~g}$ Sodium hydride was added in small portions before the reaction mixture was flushed with argon and stirred at room temperature for $1 \mathrm{~h}$. After this period, the dropwise addition of $7.77 \mathrm{~g}$ pure ethyl formate through the septum was administered. The reaction mixture was stirred over night at ambient temperature [1, 2].

On the next day, the reaction mixture has become a cloudy-orange suspension, which was evaporated to dryness. The remaining yellow solid was colloidally dissolved in water. By the addition of $1 \mathrm{M} \mathrm{HCl}$, the $\mathrm{pH}$-value (beginning 9-10) could be changed to $\mathrm{pH} 4$ and orange suspension becomes a milky white, before some white solids start to precipitate. $14.80 \mathrm{~g}$ could be obtained as an amber solid. The crude product was still wet. This material was purified by column chromatography on silica gel by using hexane-ethyl acetate (8:2) as an eluent. $12.0 \mathrm{~g}$ light beige solid could be obtained as a purified product (85\%).

MS (ESI $)^{+}$:

$\mathrm{m} / \mathrm{z}=402.94$ (calculated MW: $402.57 \mathrm{~g} / \mathrm{mol}$ )

$\mathrm{R}_{\mathrm{f}}: \quad 0.6$, hexane/ethyl acetate 7:3, UV active ( $\left.254 \mathrm{~nm}\right)$, and visualized by Seebach derivatization reagent. 
<smiles>C[C@H]1CC2(C)C(CCC3C2CCC2(C)C3CC[C@@H]2O)CC1=O</smiles>

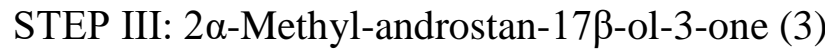

In this "one-pot-reaction"-step the conversion to the $1 \alpha$-methyl-group is performed simultaneously with the cleavage of the protective group at the $17 \beta$-alcohol:

$10.60 \mathrm{~g}$ Hydroxymethylene-precusor 2 was nearly dissolved in $800 \mathrm{ml}$ ethanol at $55^{\circ} \mathrm{C}$. This solution was hydrogenated in a pressure vessel (Parr reactor) with $6.00 \mathrm{~g}$ palladium on charcoal (5\%) at 4 bar and room temperature for $24 \mathrm{~h}$. The mixture was filtered twice through paper and the corresponding ethanol solution was evaporated, to yield 9.50 g colorless oil, still contains traces of charcoal and ethanol. The crude product was purified by column chromatography on silica gel by using hexane-ethyl acetate (8:2) as an eluent, to afford 5.45 g purified material as a colorless solid $(\mathbf{6 9 \%})$ [1, 2].

MS (ESI $\left.{ }^{+}\right)$:

$m / z=304.96$ (calculated MW: $304.47 \mathrm{~g} / \mathrm{mol}$ )

$\mathrm{R}_{\mathrm{f}}: \quad 0.35$, hexane/ethyl acetate 7:3, visualized by Seebach derivatization reagent.

${ }^{1} \mathrm{H}$ NMR(300 MHz, DMSO-d $): \delta 4.42(\mathrm{~d}, 1 \mathrm{H}, \mathrm{OH}), 3.42\left(\mathrm{~m}, 1 \mathrm{H}, \mathrm{H}_{\mathrm{CHOH}}\right), 3.32(\mathrm{~s}, 1 \mathrm{H}, \mathrm{CH})$, 2.37 (t, $1 \mathrm{H}, \mathrm{CH}), 1.99$ (dd, $1 \mathrm{H}$, ), 1.84 (dd, 1H), $1.78-1.84$ (m, 1H), 1.72 (m, 1H), 1.61 (m, $1 \mathrm{H}), 1.22-1.58(\mathrm{~m}, 8 \mathrm{H}), 1.08-1.22(\mathrm{~m}, 1 \mathrm{H}), 1.03\left(\mathrm{~s}, 3 \mathrm{H}, \mathrm{CH}_{3}\right), 0.76-1.01\left(\mathrm{~m}+\mathrm{d}, 7 \mathrm{H}, 2 \alpha-\mathrm{CH}_{3}\right.$ $+\mathrm{X}), 0.65-0.72(\mathrm{~m}, 1 \mathrm{H}), 0.64\left(\mathrm{~s}, 3 \mathrm{H}, \mathrm{CH}_{3}\right)$.

\section{Preparation of methasterone:}<smiles>C[C@H]1CC2(C)C(CCC3C2CCC2(C)C3CC[C@]2(C)O)CC1=O</smiles>

$2 \alpha$-17 $\alpha$-Dimethyl-androstan-17ß-ol-3-one (4)

2.05 g Oxymetholone was dissolved in $160 \mathrm{ml}$ ethanol at room temperature. This solution was hydrogenated in a pressure vessel (Parr reactor) with 2.50 g palladium on charcoal (5\%) at 3 bar and room temperature for $36 \mathrm{~h}$. The reaction seemed to be completed, since there is no 
starting material remaining. The formation of two major byproducts can be observed via TLC (Seebach-staining). The mixture was filtered through a short pad of silica and the corresponding ethanol solution was evaporated to yield $1.90 \mathrm{~g}$ of a colorless solid [1, 2]. The crude product was purified by column chromatography on silica gel by using hexane-ethyl acetate (1:1), to afford $1.35 \mathrm{~g}$ of $\mathbf{4}$ as a colorless solid (68\%).

MS (ESI $\left.{ }^{+}\right)$:

$m / z=319.17$ (calculated MW: $318.49 \mathrm{~g} / \mathrm{mol})$

$\mathrm{R}_{\mathrm{f}}$ : 0.80 , hexane/ethyl acetate $1: 1$, visualized by Seebach derivatization reagent.

${ }^{1} \mathrm{H}$ NMR(300 MHz, CDCl $\left.3-\mathrm{d}_{3}\right): \delta 2.49$ (sept, $\left.1 \mathrm{H}, \mathrm{CH}\right), 2.34$ (t, 1H, CH), $2.13-2.05$ (m, 2H, $\left.\mathrm{CH}_{2}\right), 1.87-1.25$ (m, $\left.12 \mathrm{H}\right), 1.23$ (s, $\left.3 \mathrm{H}, \mathrm{CH}_{3}\right), 1.22$ - 1.12 (m, 2H), 1.10 (s, $\left.3 \mathrm{H}, \mathrm{CH}_{3}\right), 1.02$ (d, $\left.3 \mathrm{H}, \mathrm{CH}_{3}\right), 1.00-0.91$ (m, $\left.1 \mathrm{H}\right), 0.89\left(\mathrm{~s}, 3 \mathrm{H}, \mathrm{CH}_{3}\right), 0.88-0.80$ (m, 1H), 0.71 (td, $\left.1 \mathrm{H}, \mathrm{CH}\right)$.

\section{Preparation of 4,5a-dihydro-2-(hydroxymethylene)testosterone (oxystanolone):}<smiles>CC12CC(=CO)C(=O)CC1CCC1C2CCC2(C)C1CC[C@@H]2O</smiles>

2-Hydroxymethylene-androstan-17ß-ol-3-one (5)

To a solution of $0.95 \mathrm{~g}$ intermediate (2) in $55 \mathrm{ml}$ of the solvent mixture tetrahydrofuran/methanol/water 7:2:1 pyridinium tosylate $(1.15 \mathrm{~g}$ dissolved in $20 \mathrm{ml}$ tetrahydrofuran/methanol/water 7:2:1) was added at room temperature. Subsequently, this was followed by $8 \mathrm{~h}$ stirring at $50^{\circ} \mathrm{C}$. Monitoring via TLC still shows remaining starting material [3].

After evaporation of all solvents, the crude product was chromatographed on silica gel by using hexane-ethyl acetate (8:2). $0.385 \mathrm{~g}$ of 5 was obtained as a colorless solid (52\%).

MS (ESI ${ }^{+}$:

$m / z=318.95 \quad$ (calculated MW: $318.45 \mathrm{~g} / \mathrm{mol}$ )

$\mathrm{R}_{\mathrm{f}}$ : 0.35 , hexane/ethyl acetate $7: 3$, UV active $(254 \mathrm{~nm})$, and visualized by Seebach derivatization reagent. 


\section{Preparation of clostebol:}<smiles>CC12CCC3C(CCC45OC4C(=O)CCC35C)C1CC[C@@H]2O</smiles>

STEP I: 4,5-Epoxy-androstan-17 $\beta$-ol-3-one (6)

$10.0 \mathrm{~g}$ Testosterone was dissolved in $200 \mathrm{ml}$ methanol and cooled to $0^{\circ} \mathrm{C}$ on ice. After cooling down, a chilled sodium hydroxide solution $(1.40 \mathrm{~g}$ in $20 \mathrm{ml})$ was added dropwise, followed by the addition of $8 \mathrm{ml}$ cold $30 \%$ hydrogen peroxide solution. The reaction was then stirred for 12 $\mathrm{h}$ at $0^{\circ} \mathrm{C}$.

The reaction solution was then diluted with $500 \mathrm{ml}$ water, before the resulting suspension was extracted several times with $200 \mathrm{ml}$ dichloromethane. The combined organic phases were dried over Magnesium sulfate and all solvents were removed under vacuum [4]. This resulted in 8.50 $\mathrm{g}$ of $\mathbf{6}$ as a colorless foam (85\%).

For further conversion to Clostebol (7), this intermediate was taken without any additional purification.

$\mathrm{R}_{\mathrm{f}}: \quad 0.45$, hexane/ethyl acetate 1:1, visualized by Seebach derivatization reagent.<smiles>CC12CCC(=O)C(Cl)=C1CCC1C2CCC2(C)C1CC[C@@H]2O</smiles>

STEP II: 4-Chloro-androst-4-en-17 $\beta$-ol-3-one (7)

8.50 g epoxide (6) was dissolved in $150 \mathrm{ml}$ Acetone and treated with $14 \mathrm{ml}$ of $25 \%$ hydrochloric acid. An immediate color shift of the reaction mixture from light yellow to deep blue can be observed. After stirring for $30 \mathrm{~h}$ at room temperature, a complete conversion of the epoxide (6) can be monitored by TLC. The reaction mixture was diluted with $400 \mathrm{ml}$ water, leading to the formation of a blue-black solid precipitating from the solution. 
After evaporation of acetone, the remaining aqueous solution was extracted several times with $200 \mathrm{ml}$ dichloromethane. The combined organic extracts were washed with saturated sodium bicarbonate solution and sodium chloride solution before drying over magnesium sulfate.

The crude product was chromatographed on silica gel by using hexane-ethyl acetat (1:1) and followed by a recrystallization from acetone [4]. The isolated product 7 was obtained as yellowish crystals (4.50 g; $\mathbf{5 1 \%}$ ).

MS $\left(\mathrm{ESI}^{+}\right)$:

$m / z=322.83+324.80\left({ }^{37} \mathrm{Cl}\right)($ calculated MW: $322.87 \mathrm{~g} / \mathrm{mol})$

$\mathrm{R}_{\mathrm{f}}$ : 0.45 , hexane/ethyl acetate 4:6, UV active (254), and visualized by Seebach derivatization reagent.

${ }^{1} \mathrm{H}$ NMR(300 MHz, DMSO-d 6 ) : $\delta 4.48$ (d, $\left.1 \mathrm{H}, \mathrm{OH}\right), 3.44$ (m, 1H, HсHон), 3.05 (m, 1H, 2$\left.\mathrm{CH}_{2}\right), 2.63\left(\mathrm{~m}, 1 \mathrm{H}, 2-\mathrm{CH}_{2}\right), 2.42(\mathrm{~m}, 1 \mathrm{H}), 2.27(\mathrm{~m}, 1 \mathrm{H}), 1.98(\mathrm{~m}, 1 \mathrm{H}), 1.48-1.90(\mathrm{~m}, 7 \mathrm{H})$, $1.30-1.41$ (m, 2H), $1.25(\mathrm{~m}, 1 \mathrm{H}), 1.21$ (s, 3H, $\left.\mathrm{CH}_{3}\right), 0.84-1.03(\mathrm{~m}, 4 \mathrm{H}), 0.69\left(\mathrm{~s}, 3 \mathrm{H}, \mathrm{CH}_{3}\right)$.

\section{Preparation of boldenone:}<smiles>CC12C=CC(=O)C=C1CCC1C2CCC2(C)C1CC[C@H]2O</smiles>

1,4-Androstdien-17ß-ol-3-one (8)

$29.0 \mathrm{~g}$ Testosterone was dissolved in $220 \mathrm{ml}$ dioxan/THF 8:2 and cooled to $0^{\circ} \mathrm{C}$ on ice. After cooling down a solution of tert-butyldimethylsilyl chloride (46.0 g in $100 \mathrm{ml}$ dioxan/THF 8:2) was added dropwise and stirred for $90 \mathrm{~min}$ at $0^{\circ} \mathrm{C}$. Then a suspension of $32.0 \mathrm{~g}$ of DDQ in 200 $\mathrm{ml}$ dioxan/THF 8:2 was added in 4 equal portions over a period of $4 \mathrm{~h}$. The reaction mixture was stirred for additional $12 \mathrm{~h}$ within coming from $0^{\circ} \mathrm{C}$ to room temperature.

The resulting suspension was then filtered over Celite and rinsed with $300 \mathrm{ml}$ THF. The filtrate was evaporated and brown oil was obtained. The oil was diluted in $1500 \mathrm{ml}$ DCM and washed with $500 \mathrm{ml}$ of $5 \%$ aqueous sodium hydroxide. The yellow organic phase was washed with 400 $\mathrm{ml}$ water and $400 \mathrm{ml}$ saturated sodium chloride solution, before drying over magnesium sulfate.

After evaporation, the crude product was chromatographed on silica gel by using hexane-ethyl acetate (3:7), followed by a recrystallization in ethyl acetate [5]. $16.50 \mathrm{~g}$ of $\mathbf{8}$ was obtained as an amber solid (58\%). 
MS $\left(\mathrm{ESI}^{+}\right)$:

$m / z=287.20$ (calculated MW: $286.41 \mathrm{~g} / \mathrm{mol})$

$\mathrm{R}_{\mathrm{f}}$ : $\quad 0.30$, hexane/ethyl acetate $3: 7$, UV active $(254 \mathrm{~nm})$, and visualized by Seebach derivatization reagent

${ }^{1} \mathrm{H}$ NMR(300 MHz, $\mathrm{CDCl}_{3}$ ) : $\delta 7.05$ (d, $\left.1 \mathrm{H}, \mathrm{H}_{\text {olefin }}\right), 6.23$ (d, $\left.1 \mathrm{H}, \mathrm{H}_{\text {olefin }}\right), 6.07$ (s, $1 \mathrm{H}, \mathrm{H}_{\text {olefin }}$ ), 3.64 (t, 1H, $\left.\mathrm{H}_{\mathrm{CHOH}}\right), 2.42-2.51$ (m, 1H), $2.32-2.39$ (m, 1H), $2.02-2.12$ (m, 1H), 1.91-1.99 (m, 1H), $1.84-1.90$ (m, 1H), $1.56-1.80$ (m, 4H), $1.41-1.51$ (m, 2H), $1.28-1.39(\mathrm{~m}, 1 \mathrm{H})$, 1.24 (s, 3H, $\left.\mathrm{CH}_{3}\right), 0.91-1.14(\mathrm{~m}, 4 \mathrm{H}), 0.82$ (s, 3H, $\left.\mathrm{CH}_{3}\right)$.

\section{Preparation of LGD-2226:}<smiles>O=c1cc(C(F)(F)F)c2ccccc2[nH]1</smiles>

STEP I: 4-Trifluoromethylquinolin-2(1H)-one (9)

In a $1 \mathrm{~L}$ round flask fitted with a reflux condenser a mixture of $25.60 \mathrm{~g}$ aniline, $50.0 \mathrm{~g}$ ethyl4,4,4-trifluoroacetoacetate $300 \mathrm{ml}$ toluene was heated to reflux in an oil bath at $130{ }^{\circ} \mathrm{C}$. After $20 \mathrm{~min} 3 \mathrm{ml}$ water was added and the mixture was heated at reflux for another $24 \mathrm{~h}$. the reaction mixture was cooled to room temperature and concentrated under reduced pressure. A round flask with $200 \mathrm{~mL} \mathrm{H}_{2} \mathrm{SO}_{4}$ was heated to $80^{\circ} \mathrm{C}$ and the crude oil from the step before was added in portions to the $\mathrm{H}_{2} \mathrm{SO}_{4}$ keeping the internal temperature below $90^{\circ} \mathrm{C}$, total addition time was approximately $40 \mathrm{~min}$. After addition was complete, the mixture was stirred at $80^{\circ} \mathrm{C}$ for $1 \mathrm{~h}$, cooled and poured onto $400 \mathrm{~g}$ crushed ice. The resulting solids were filtered, washed with water, and dried under vacuum at $40^{\circ} \mathrm{C}$ to give 33.0 g (50\%) product (9) as a colorless solid [6, 7].

MS (ESI $\left.{ }^{+}\right)$:

$m / z=214.13$ (calculated MW: $213.16 \mathrm{~g} / \mathrm{mol}$ )

$\mathrm{R}_{\mathrm{f}}$ : 0.10, hexane/ethyl acetate 7:3, UV active (254 nm). 
<smiles>O=c1cc(C(F)(F)F)c2cc([N+](=O)[O-])ccc2[nH]1</smiles>

STEP II: 6-Nitro-4-trifluoromethylquinolin-2(1H)-one (10)

A milky suspension of $33.0 \mathrm{~g}$ in $200 \mathrm{~mL} \mathrm{H}_{2} \mathrm{SO}_{4}$ was cooled in an ice-salt bath to $-5^{\circ} \mathrm{C} .14 .3 \mathrm{~g}$ $70 \% \mathrm{HNO}_{3}$ was added dropwise, keeping the internal temperature below $7^{\circ} \mathrm{C}$. After addition was complete, the mixture was stirred at $0-10^{\circ} \mathrm{C}$ for $1 \mathrm{~h}$ and then after removal of the ice bath the temperature raised to room temperature within the next hours. The yellow solution was then poured onto $600 \mathrm{~g}$ crushed ice and kept standing/stirring for the next $12 \mathrm{~h}$. The resulting two phases were separated and the organic phase equals a yellow slurry, which was filtered by suction. The resulting solid was washed with water and dried under vacuum. After crystallization of $20 \mathrm{~g}$ crude product in $1 \mathrm{~L}$ ethanol a nearly colorless solid (10) (43\%) was obtained [6, 7].

MS (ESI-):

$m / z=257.08+514.96(2 * \mathrm{M})($ calculated MW: $258.15 \mathrm{~g} / \mathrm{mol})$<smiles>Nc1ccc2[nH]c(=O)cc(C(F)(F)F)c2c1</smiles>

STEP III: 6-Amino-4-trifluoromethylquinolin-2(1H)-one (11)

A suspension of the $17.0 \mathrm{~g}$ Nitro-compound (10) in $400 \mathrm{ml}$ ethanol in a $1 \mathrm{~L}$ round flask was flushed with argon and $2.0 \mathrm{~g} 5 \% \mathrm{Pd} / \mathrm{C}$ was added. The mixture was stirred under a hydrogen atmosphere for 2 days. Then filtered through silica and washed with $1500 \mathrm{~mL}$ ethanol. The filtrate was evaporated under vacuum to yield $14.0 \mathrm{~g}$ of a bright yellow solid $11(\mathbf{9 2 \%})$.

Since the resulting solid has been monitored by TLC to exhibit high purity, the product was used without further purification for the next step.

MS (ESI $)^{+}$:

$\mathrm{m} / \mathrm{z}=229.11$ (calculated MW: $228.17 \mathrm{~g} / \mathrm{mol}$ ) 
<smiles>O=c1cc(C(F)(F)F)c2cc(N(CC(F)(F)F)CC(F)(F)F)ccc2[nH]1</smiles>

STEP IV: 6-N,N-Bis(2,2,2-trifluoroethyl)amino -4-trifluoromethylquinolin-2(1H)-one (12)

A $2 \mathrm{~L}$ round flask, under argon, was charged with a solution of the $14.00 \mathrm{~g}$ amine 11 in $350 \mathrm{ml}$ trifluoroacetic acid. $5.80 \mathrm{~g} \mathrm{NaBH}_{4}$ was added within $1 \mathrm{~h}$. The mixture was stirred at room temperature for $16 \mathrm{~h}$. After that $4.50 \mathrm{~g} \mathrm{NaBH}_{4}$ was added and then heated to $70^{\circ} \mathrm{C}$ for $5 \mathrm{~h}$. The heating bath was removed and it was stirred at room temperature over $2 \mathrm{~d}$. In several portions water was carefully added. In total $1500 \mathrm{ml}$ water was slowly added. The yellow-greenish precipitate was filtered and rinsed with water.

After drying, the crude product was purified by column chromatography on silica gel by using hexane-ethyl acetate (1:4), followed by a recrystallization in chloroform [6]. $18.1 \mathrm{~g}$ of 12 was obtained as a bright yellow solid (76\%).

MS (ESI $)^{+}$:

$m / z=392.86$ (calculated MW: $392.22 \mathrm{~g} / \mathrm{mol}$ )

$\mathrm{R}_{\mathrm{f}}: \quad 0.35$, hexane/ethyl acetate 1:4, UV active $(254 \mathrm{~nm})$.

${ }^{1} \mathrm{H}$ NMR(300 MHz, DMSO-d $): \delta 12.2$ (bs, $\left.1 \mathrm{H}, \mathrm{NH}\right), 7.57$ (dd, 1H, $\left.\mathrm{H}_{\text {arom }}\right), 7.39$ (d, 1H, $\mathrm{H}_{\text {arom }}$ ), 7.16 (s, $1 \mathrm{H}, \mathrm{H}_{\text {arom }),} 6.97$ (s, $\left.1 \mathrm{H}, \mathrm{H}_{\text {olefin }}\right), 4.39$ (q, 4H, $\mathrm{CH}_{2}$ ).

Preparation of LGD-4033:<smiles>N#Cc1ccc(N2CCCC2CO)cc1C(F)(F)F</smiles>

STEP I: 4-(2-(hydroxymethyl)-pyrrolidin-1-yl)-2-(trifluoromethyl)benzonitril (13)

10.0 g 4-Fluoro-2-(trifluoromethyl)benzonitril was dissolved in $200 \mathrm{ml}$ tetrahydrofuran and 9.0 $\mathrm{ml}$ Hünig base was added dropwise. While stirring at room temperature, $5.0 \mathrm{~g}$ D-prolinol diluted in $100 \mathrm{ml}$ tetrahydrofuran was added over a period of $15 \mathrm{~min}$. The reaction mixture was stirred for $2 \mathrm{~d}$ at room temperature. 
After evaporation, the crude product appears as a yellow oil, which was chromatographed on silica gel by using hexane-ethyl acetate (1:1) as a eluent to yield $11.40 \mathrm{~g}$ of $\mathbf{1 3}$ as a light yellow oil $(\mathbf{8 8 \%})$ [8].

MS (ESI $\left.{ }^{+}\right)$:

$m / z=270.89$ (calculated MW: $270.25 \mathrm{~g} / \mathrm{mol}$ )

$\mathrm{R}_{\mathrm{f}}$ : 0.30 , hexane/ethyl acetate 1:1, UV active (254 nm).<smiles>N#Cc1ccc(N2CCCC2C=O)cc1C(F)(F)F</smiles>

STEP II: 4-(2-(formylpyrrolidin-1-yl)-2-(trifluoromethyl)benzonitril (14)

6.99 g Oxalylchloride was diluted in $100 \mathrm{ml}$ dichloromethane and cooled down to $-78^{\circ} \mathrm{C}$ by dry ice/acetone bath. $9.83 \mathrm{~g}$ dimethylsulfoxide diluted in $50 \mathrm{ml}$ dichloromethane was added via syringe over a period of $30 \mathrm{~min}$. After stirring $20 \mathrm{~min}$ at $-78^{\circ} \mathrm{C}, 11.4 \mathrm{~g}$ intermediate-alcohol 13 diluted in $60 \mathrm{ml}$ dichloromethane is added dropwise over a period of $45 \mathrm{~min}$. After stirring 45 min at $-78^{\circ} \mathrm{C}$, the addition of $29 \mathrm{ml}$ triethylamine starts, following by $30 \mathrm{~min}$ stirring at $-78^{\circ} \mathrm{C}$.

Then the ice bath was removed and the reaction mixture was stirred $12 \mathrm{~h}$ at room temperature. The resulting yellow-milky suspension was stirred with $200 \mathrm{ml}$ saturated sodium chloride solution. After the separation of the organic phase, the aqueous phase was extracted two times with $100 \mathrm{ml}$ dichloromethane. The combined organic phases were dried over magnesium sulfate and evaporated. The resulting yellow solid was purified by column chromatography on silica gel by using hexane-ethyl acetate (1:1) as a eluent [8]. $11.20 \mathrm{~g}$ of $\mathbf{1 4}$ was obtained as a yellow solid (99\%).

MS $\left(\mathrm{ESI}^{+}\right)$:

$m / z=269.08$ (calculated MW: $268.23 \mathrm{~g} / \mathrm{mol}$ )

$\mathrm{R}_{\mathrm{f}}$ : 0.40 , hexane/ethyl acetate $1: 1$, UV active (254 $\left.\mathrm{nm}\right)$. 
<smiles>N#Cc1ccc(N2CCCC2(C(O)(F)F)C(F)(F)F)cc1C(F)(F)F</smiles>

STEP III: 4-(2-(1-Hydroxyl-2,2,2-trifluoroethyl)pyrrolidin-1-yl)-2(trifluoromethyl)benzonitril (15)

11.20 g Aldehyde 14 was dissolved in $300 \mathrm{ml}$ dry tetrahydrofuran and $8.36 \mathrm{~g}$ CsF was added directly as a solid to the reaction mixture. It was cooled via ice bath to $0^{\circ} \mathrm{C}$ and stirred for 15 min. Then $25.00 \mathrm{~g}$ trimethyl(trifluoromethyl)silane was added via syringe over a period of 40 min. The reaction is stirred for $15 \mathrm{~h}$ coming from $0^{\circ} \mathrm{C}$ to room temperature over this time interval. The reaction solution shifts color from nearly colorless to dark brown.

For stopping the reaction, it was diluted with $100 \mathrm{ml}$ saturated ammonium chloride solution and then evaporated. The resulting emulsion was extracted several times with ethyl acetate and the combined phases dried over magnesium sulfate. After evaporation of all volatiles, the intermediate silyl-ether can be obtained as red-brown oil.

This intermediate was converted to the final product $\mathbf{1 5}$ without any further purification.

The intermediate was diluted with $400 \mathrm{ml}$ tetrahydrofuran and cooled to $0^{\circ} \mathrm{C}$. A cooled potassium hydroxide solution ( $4.76 \mathrm{~g}$ in $400 \mathrm{ml}$ water) was mixed with the diluted oil and stirred at $0^{\circ} \mathrm{C}$ for $2 \mathrm{~h}$. After quenching with $300 \mathrm{ml}$ water, the organic solvent was removed via evaporation from the mixture. The remaining brown oil was extracted with dichloromethane and dried over magnesium sulfate, to yield a reddish-brown oil.

This crude product was chromatographed on silica gel by using hexane-ethyl acetat (8:2) as an eluent. During purification, different fractions with several product isomers can be collected [8].

The isolated products were obtained as 8.50 g yellowish oils $(\mathbf{6 1 \% )}$.

MS (ESI ${ }^{+}$):

$\mathrm{m} / \mathrm{z}=338.97$ (calculated MW: $338.25 \mathrm{~g} / \mathrm{mol}$ )

$\mathrm{R}_{\mathrm{f}}: 0.65+0.50$ (isomers), hexane/ethyl acetate 1:1, UV active (254 nm $\left.+366 \mathrm{~nm}\right)$.

${ }^{1} \mathrm{H}$ NMR(300 MHz, DMSO-d 6 ): $\delta 7.85$ (d, 1H, Harom), 6.94 (d, 1H, $\mathrm{H}_{\text {arom }}$ ), 6.87 (dd, $1 \mathrm{H}$,

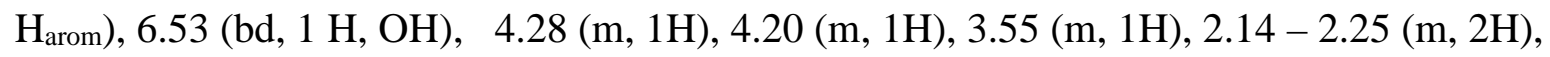
$1.89-2.02(\mathrm{~m}, 2 \mathrm{H})$. 


\section{Conflicts of Interest}

Matthias Grill was an employee of Lipomed AG, Switzerland. The other authors declare no conflict of interest.

\section{References}

[1] H.J. Ringold, E. Batres, O. Halpern, E. Necoechea, Steroids. CV.1 2-Methyl and 2Hydroxymethylene-androstane Derivatives, Journal of the American Chemical Society 81(2) (1959) 427-432.

[2] R.O. Clinton, R.L. Clarke, F.W. Stonner, A.J. Manson, K.F. Jennings, D.K. Phillips, Steroidal Heterocycles. VI.1 Formylation of A/B-cis 3-Ketosteroids.2 Preparation of 5 $\beta$ Steroidal[3,2-c]pyrazoles, The Journal of Organic Chemistry 27(8) (1962) 2800-2807.

[3] M. Miyashita, A. Yoshikoshi, P.A. Grieco, Pyridinium p-toluenesulfonate. A mild and efficient catalyst for the tetrahydropyranylation of alcohols, The Journal of Organic Chemistry 42(23) (1977) 3772-3774.

[4] H.J. Ringold, E. Batres, O. Mancera, G. Rosenkranz, Steroids. LXXXII.1 Synthesis of 4Halo Hormone Analogs, The Journal of Organic Chemistry 21(12) (1956) 1432-1435.

[5] K. Chen, C. Liu, L. Deng, G. Xu, A practical Delta 1-dehydrogenation of Delta 4-3-ketosteroids with DDQ in the presence of TBDMSCl at room temperature, Steroids 75(7) (2010) 513-6.

[6] A. van Oeveren, M. Motamedi, N.S. Mani, K.B. Marschke, F.J. Lopez, W.T. Schrader, A. Negro-Vilar, L. Zhi, Discovery of 6-N,N-bis(2,2,2-trifluoroethyl)amino- 4trifluoromethylquinolin-2(1H)-one as a novel selective androgen receptor modulator, Journal of medicinal chemistry 49(21) (2006) 6143-6.

[7] M. Marull, O. Lefebvre, M. Schlosser, An Improved Access to 4-Trifluoromethyl-2(1H)quinolinones: The "Watering Protocol”, 2004(1) (2004) 54-63.

[8] L. Zhi, SELECTIVE ANDROGEN RECEPTOR MODULATORS (SARMS) AND USES THEREOF, PCT International Application, WO/2009/082437 (2009). 